\title{
Research of effectiveness of diffusive samplers determining nitrogen dioxide in air
}

\author{
Janina Tarvydaité, Agnè Kazlauskienè \\ Vilnius Gediminas Technical University, Faculty of Environmental Engineering, Sauletekis av. 11, Vilnius LT-10223, Lithuania
}

\begin{abstract}
Passive samplers are widely used for ambient air monitoring because of low-cost, convenient way for mapping spatial distributions and ability to investigate long term trends of nitrogen dioxide $\left(\mathrm{NO}_{2}\right)$. During investigations there are used passive diffusive tubes which are capable to take the samples of gases from the atmosphere at a rate controlled by gaseous diffusion through a static air layer but do not involve the active movement of air. Gasses diffuse along a sampler onto impregnated filter or mash with absorbing or adsorbing medium. In this research three different absorbents were selected: 10\% of TEA (triethanolamine) diluted in water, 10\% of TEA diluted in acetone and potassium iodide $(\mathrm{KI})$ with sodium hydroxide $(\mathrm{NaOH})$. Passive samplers with these solutions have been used for experimental research, which was carried out under field conditions in the roadside of district road with composed cross-sections. The results have shown that samplers impregnated with $10 \%$ of TEA diluted in water reveals the greatest accuracy in comparison of $\mathrm{NO}_{2}$ measuring results near automatic air monitoring station (AMS). According to the precision, both $10 \%$ of TEA diluted in water and $10 \%$ of TEA diluted in acetone comply with the Directive 2008/50/EC requirement for uncertainty $(<25 \%)$.
\end{abstract}

Keywords: Passive samplers; triethanolamine; nitrogen dioxide; potassium iodide; sodium hydroxide.

\section{Introduction}

The main anthropogenic sources of nitrogen dioxide are mobile (motor vehicles) and stationary (heating, power generation) combustion sources [30]. However, commonly this contaminant is formed when molecular nitrogen combines with atmospheric oxygen in burning process in engines [12]. Nitrogen dioxide is a toxic gas and thus a regulated air pollutant. This contaminant was continuously investigated because of its negative impact to human health and environment, likewise the participation as a precursor of secondary pollutants such as troposphere ozone, aerosol nitrate, and the hydroxyl radical $(\mathrm{OH})[22,33]$. Both short-term of high concentration of nitrogen dioxide and long-term exposure of lower concentration can affect the airways; long time exposure can cause serious diseases, such as asthma, lung damage, heart diseases or even increase the mortality $[5,14]$.

Various studies have been carried out to assess the impact of environmental parameters on outdoor concentration of nitrogen dioxide. There was evaluated, that air pollution in city centres and districts near highways is related to traffic density of the highway including the distance of the measuring site to the highway [4]. With reference to Gilbert et al. concentrations of $\mathrm{NO}_{2}$ decreases as distance from the highway increases, and are systematically higher downwind than upwind [12]. The major decrease was estimated within $200 \mathrm{~m}$ of the highway. Operating conditions such as speed of vehicle and acceleration which are affected by different environmental factors (traffic signals, speed limits, interventions, etc.) also influence the amount of pollution. In this case, concentrations are in parallel with fuel consumption and increase when driving uphill or by transient driving modes such as acceleration and deceleration [15, 28]. Considering pollution near the road, it also depends on configuration and arrangement of buildings, the spacing between them, and width of streets [7]. Other environmental factors are meteorological conditions (e.g. wind speed, temperature, rainfall). On these conditions depends whether the pollutants on atmosphere will accumulate in the exhaust points or will be scattered in the area [2, 19].

There are developed many different techniques for $\mathrm{NO}_{2}$ measuring in the laboratory and/or in the field (spectroscopic, ion chromatography, colorimetric samples, electrochemical sensors, etc.) [29, 33]. One of these techniques is passive sampling which is based on free flow of analyte molecules from the sampled medium to a collecting medium as a result of a difference in chemical potentials [13]. The advantages of passive samplers are related to elimination of power requirements,

Corresponding author: Janina Tarvydaite. E-mail address: janina.tarvydaite@stud.vgtu.lt

http://dx.doi.org/10.3846/enviro.2014.063

(C) 2014 The Authors. Published by VGTU Press. This is an open-access article distributed under the terms of the Creative Commons Attribution License, which permits unrestricted use, distribution, and reproduction in any medium, provided the original author and source are credited. 
reduction of the cost of analysis, minimal training, low detection limit and possibility to measure nitrogen dioxide concentrations in different areas [13, 29]. All passive samplers operate on the principle of diffusion of gases from the atmosphere along a sampler of defined dimensions onto an adsorbing or absorbing (a solid base impregnated with a chemical reagent) medium. The gas molecules are transferred from the ambient air into the sampling device by molecular diffusion, which is a function of temperature and pressure [10].

Several types of absorbents have been used for nitrogen dioxide measuring with passive samplers: potassium iodide in conjunction with sodium hydroxide to maintain high surface alkalinity of the reagent surface, required for long-term exposure [11], sodium carbonate $\left(\mathrm{Na}_{2} \mathrm{CO}_{3}\right) / 1 \%$ glycerine-impregnated filter paper - for badge-type sampler with a fine stainless mesh diffusion membrane [9], a new collection medium ChemixTM [8]. However, the most commonly used absorbent for $\mathrm{NO}_{2}$ is triethanolamine (TEA) where the gas is converted to nitrite ions. TEA has been used for $\mathrm{NO}_{2}$ measuring by passive sampling technique since the 1970 s with a high capacity $(90-100 \%)$ to remove $\mathrm{NO}_{2}$ from the sampled air [6].

In this study modified absorbents are compared to the explored one by measuring the concentrations of nitrogen dioxide under the field conditions.

\section{Experimental}

\subsection{Construction of passive samplers}

The construction and geometry of passive sampler was chosen under the investigations of Šerevičienė [23, 25] which have shown the lowest relative uncertainty and the highest absorption rate in comparison to the other investigated samplers. The diffusion tube consists of polypropylene tube $(34 \mathrm{~mm}$ in depth and $21 \mathrm{~mm}$ in inner diameter), cover, stainless steel grid or glass fiber filter and retaining ring (Fig. 1).

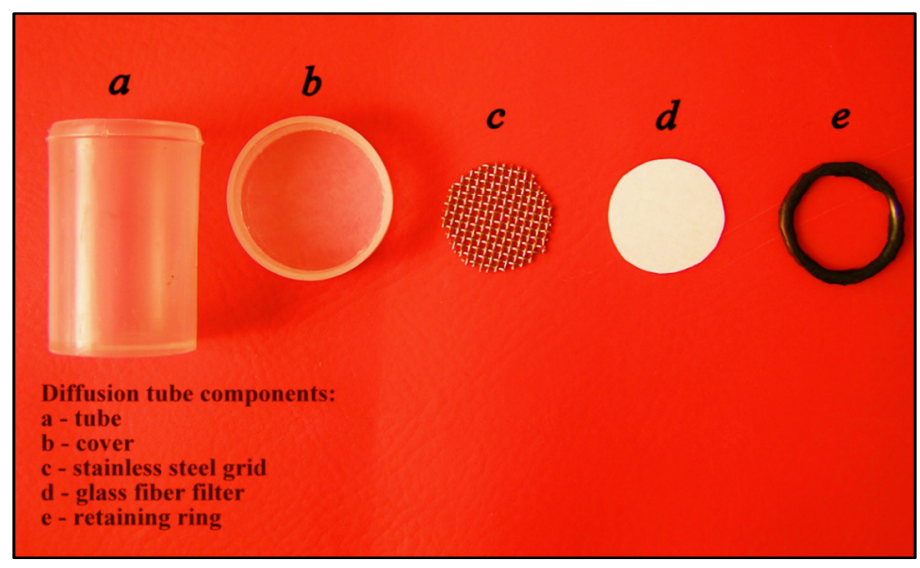

Fig. 1. Components of diffusive tube $[23,25]$

In accordance to prevention of diffusive samplers from meteorological factors and wind effect, the samplers are fixed into protective shelter. The bottom of the shelter is opened that the air can get inside.

\subsection{Application of absorbents on passive samplers}

In this research three different types of absorbents were used during the same time. As the most common absorbent, triethanolamine diluted in water was chosen according to previous investigations, which ensured the reliability of the sink. The decision to choose $10 \%$ of TEA diluted in water for nitrogen dioxide absorption was determined by relative precision, which is appropriate to EU directive $(2008 / 50 / \mathrm{EB})[18,23,25]$. There are several documents describing the use of TEA diluted in acetone as well $[6,20]$. Therefore, the comparative solution was made from $10 \%$ of TEA diluted in acetone. The second comparative absorbent was potassium iodide and sodium hydroxide which was modified considering the investigations of Ferm and Rodhe [11].

TEA solution: the preparation method for TEA solution in acetone is the same as in the water. $5 \mathrm{ml}$ of TEA is diluted up to $50 \mathrm{ml}$ mark in volumetric flask with deionized water or acetone. After the solution is mixed, it is ready to be used [1].

Potassium iodide and sodium hydroxide: the coating solution is prepared with $0.44 \mathrm{~g}$ of $\mathrm{NaOH}$ and $3.57 \mathrm{~g}$ of KI diluted up to $50 \mathrm{ml}$ mark in volumetric flask with deionized water.

After the solutions are prepared, $50 \mu \mathrm{l}$ of each solution are applied by micropipette on the grids or filters, which are placed into the tubes. The solution over the grids is spread as evenly as possible. The tubes are not handled roughly, or inverted immediately, as the solution may dribble down the inside of the tube walls. Samplers are sealed and numbered in appropriate sequence [1]. 


\subsection{Exposure site and analysis of passive samplers}

Diffusion tubes were delivered into exposure site as soon as prepared for the use. For investigations district road No. 5214 (Bukiškis - Maišiagala) which is located in the district of Vilnius was selected. An approximate traffic volume in the location of research was 3000 automobiles per day in 2012. There were the cross-section composed whereby the sampling points were located in a distance of $7.5 \mathrm{~m}, 20 \mathrm{~m}, 50 \mathrm{~m}, 100 \mathrm{~m}, 150 \mathrm{~m}, 200 \mathrm{~m}$ to the both sides of the road (to the east and west side) for evaluation of dispersion of $\mathrm{NO}_{2}$ under the distance from the road axis [3, 15, 16, 31].

The tubes were positioned vertically with open end (downwards) in the protective shelters for two weeks in each sampling point. Samplers were hanged in a 3 meter high to ensure the protection of passive samplers from spoliation.

The effectiveness of each absorbent was determined by comparing the measured results with the data provided by automatic air monitoring station where additional samplers have been exposed. The investigation was repeated four times during different seasons (spring, summer, autumn and winter) to evaluate the influence of meteorological conditions on concentration of nitrogen dioxide.

After exposure time (14 days) the samplers covered by hoods and placed into sealable bags were transported to the laboratory for extraction. Chemical analysis of exposed passive samplers was performed spectrophotometrically by using Saltzman's reagent (for absorbents based on TEA) and Griess reagent (for potassium iodide and sodium hydroxide). The amount of nitrite ion in the sample was obtained after the calibration plot of standard solutions was determined. Ambient $\mathrm{NO}_{2}$ concentrations were calculated by considering the amount of extracted nitrite from the samplers [21, 24].

\section{Results}

The results of measured nitrogen dioxide concentration near the road were compared to the changes of meteorological conditions: average temperature, average wind speed and relative humidity (Table 1).

Table 1. Meteorological conditions during the period of studies

\begin{tabular}{llll}
\hline Season & $\begin{array}{l}\text { Temperature }\left({ }^{\circ} \mathrm{C}\right) \\
\text { Min; Max; Mean }\end{array}$ & Wind speed $(\mathrm{m} / \mathrm{s})$ & $\begin{array}{l}\text { Relative humidity }(\%) \\
\text { Min; Max; Mean }\end{array}$ \\
\hline Spring & $12.5 ; 21.0 ; 16.9$ & 1.58 & $44 ; 82 ; 62$ \\
Summer & $14.9 ; 24.3 ; 19.2$ & 1.39 & $61 ; 93 ; 74$ \\
Autumn & $2.3 ; 12.2 ; 7.6$ & 2.03 & $71 ; 94 ; 86$ \\
Winter & $-9.9 ; 7.8 ; 0.9$ & 2.68 & $69 ; 97 ; 91$ \\
\hline
\end{tabular}

There were several investigators $[19,26,27,32]$ who made the researches and interpretations about the influence of meteorological conditions on air pollution by nitrogen dioxide. The current study shows a difference between nitrogen dioxide concentrations among the seasons as well. The highest concentrations in the nearest sapling points (considering the road) were measured by samplers with TEA diluted in water, acetone and KI plus NaOH during winter season $\left(15.34 \mu \mathrm{g} / \mathrm{m}^{3}\right.$, $16.22 \mu \mathrm{g} / \mathrm{m}^{3}, 8.34 \mu \mathrm{g} / \mathrm{m}^{3}$ respectively), while the lowest pollution by nitrogen dioxide was determined in summer season $\left(9.80 \mu \mathrm{g} / \mathrm{m}^{3}, 11.43 \mu \mathrm{g} / \mathrm{m}^{3}, 6.28 \mu \mathrm{g} / \mathrm{m}^{3}\right.$ respectively) (Fig. 2). There also can been seen a slight difference of concentrations at each sampling point including the side from the road.

To compare the results with previous investigations statistical analysis was carried out. However, the correlation between nitrogen dioxide and aforementioned meteorological conditions was insignificant (significance level $p$ was higher than 0.05). This could happen because of low number of values. Whereas there is no ability to approve the direct influence of mentioned factors on measured concentration, there can be made a presumption that the difference of results among the seasons depends on changes of traffic flow as Silva et al. [26] claimed. Considering this, pollution of nitrogen dioxide is lower in summer because of reduced traffic flow due to summer holidays while in winter is higher because of increased traffic flow because of pre-Christmas period (winter investigation was made on 1-14 days of December). Concerning the period of heating of the buildings, measured concentrations might have to increase due to increased background pollution. Especially due to the fact that the experiments were carried out in the village where many homes are heated by solid fuel.

To evaluate the impact of wind direction on the concentration of nitrogen dioxide, the prevailing direction of wind was determined. During summer, autumn and winter investigations predominant wind direction was north, north-west, while in spring it was mutable: three-fifths of the investigation period the east, north-west and south-east wind was blowing. Figure above confirms that the concentration of nitrogen dioxide was higher in the leeward roadside. In spring concentrations were higher in the west side from the road until the measuring point in 50 meters (after this point concentrations decreased almost half). In summer, autumn and winter the concentrations were higher in the east side from the road.

There was determined a strong negative correlation between the concentration of nitrogen dioxide and distance from the road axis showing that the concentration is decreasing when the distance increases. Table 2 describes Pearson coefficients $(r)$ with significance levels $(p)$ derived after analysis of liaison between the distance and concentration measured by different passive samplers during all research period. 

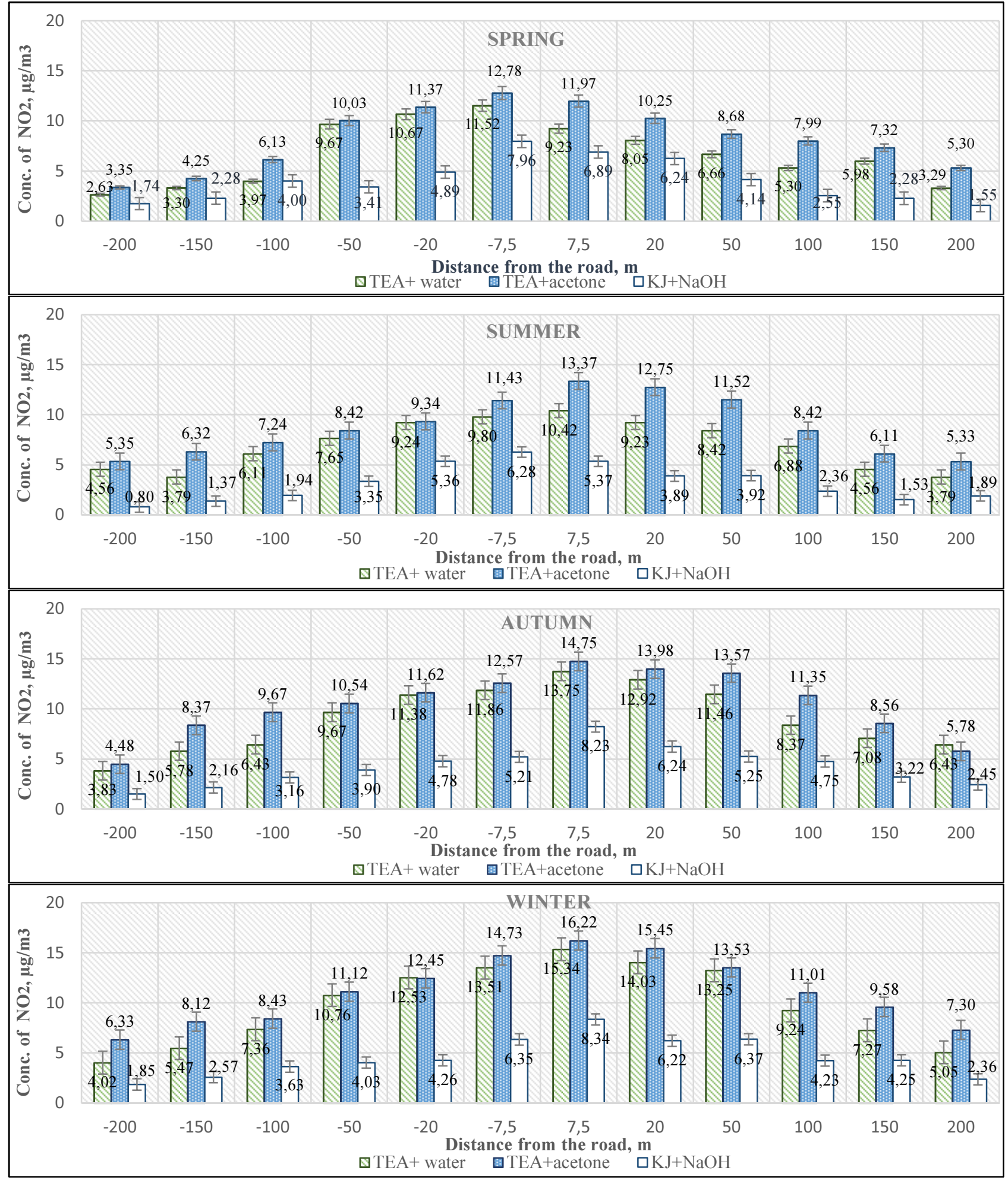

Fig. 2. Measured concentration with standard deviation of nitrogen dioxide during different seasons

Table 2. Pearson coefficients and significance levels derived from statistical analysis

\begin{tabular}{llcc}
\hline Season & TEA + water & TEA + acetone & KI + NaOH \\
& $r ; p$ & $r ; p$ & $r ; p$ \\
\hline Spring & $-0.890 ; 0.000$ & $-0.878 ; 0.000$ & $-0.889 ; 0.000$ \\
Summer & $-0.964 ; 0.000$ & $-0.859 ; 0.000$ & $-0.906 ; 0.000$ \\
Autumn & $-0.937 ; 0.000$ & $-0.964 ; 0.000$ & $-0.951 ; 0.000$ \\
Winter & $-0.967 ; 0.000$ & $-0.922 ; 0.000$ & $-0.879 ; 0.000$ \\
\hline
\end{tabular}


As shown in the table, Pearson cofeicents slightly differ among the seasons and absorbents. Figure 3 graphically displays the highest depencence of variables what was estimated in winter season while absorbent for $\mathrm{NO}_{2}$ measuring was $10 \%$ of TEA diluted in water.

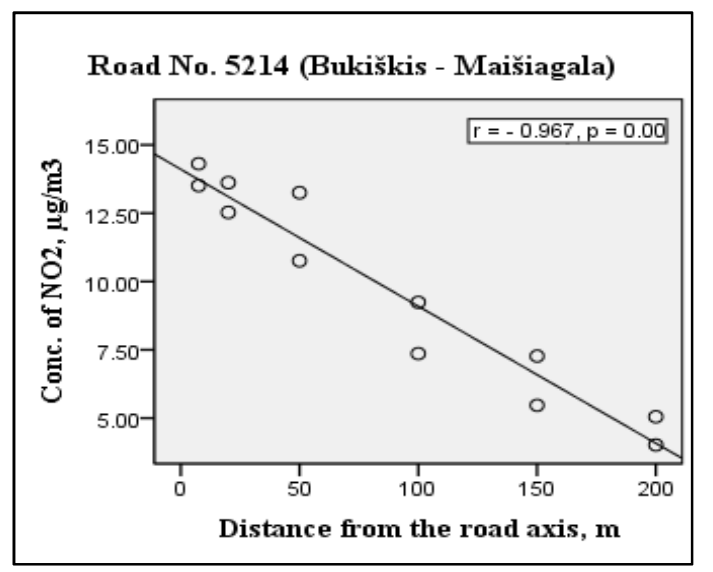

Fig. 3. Correlation between nitrogen dioxide and distance from the road

As evidenced by the figures above, samplers with different absorbents have shown different results. Figure 4 shows the results which derived from investigations near automatic air monitoring station and comparison between obtained values and data provided by AMS.

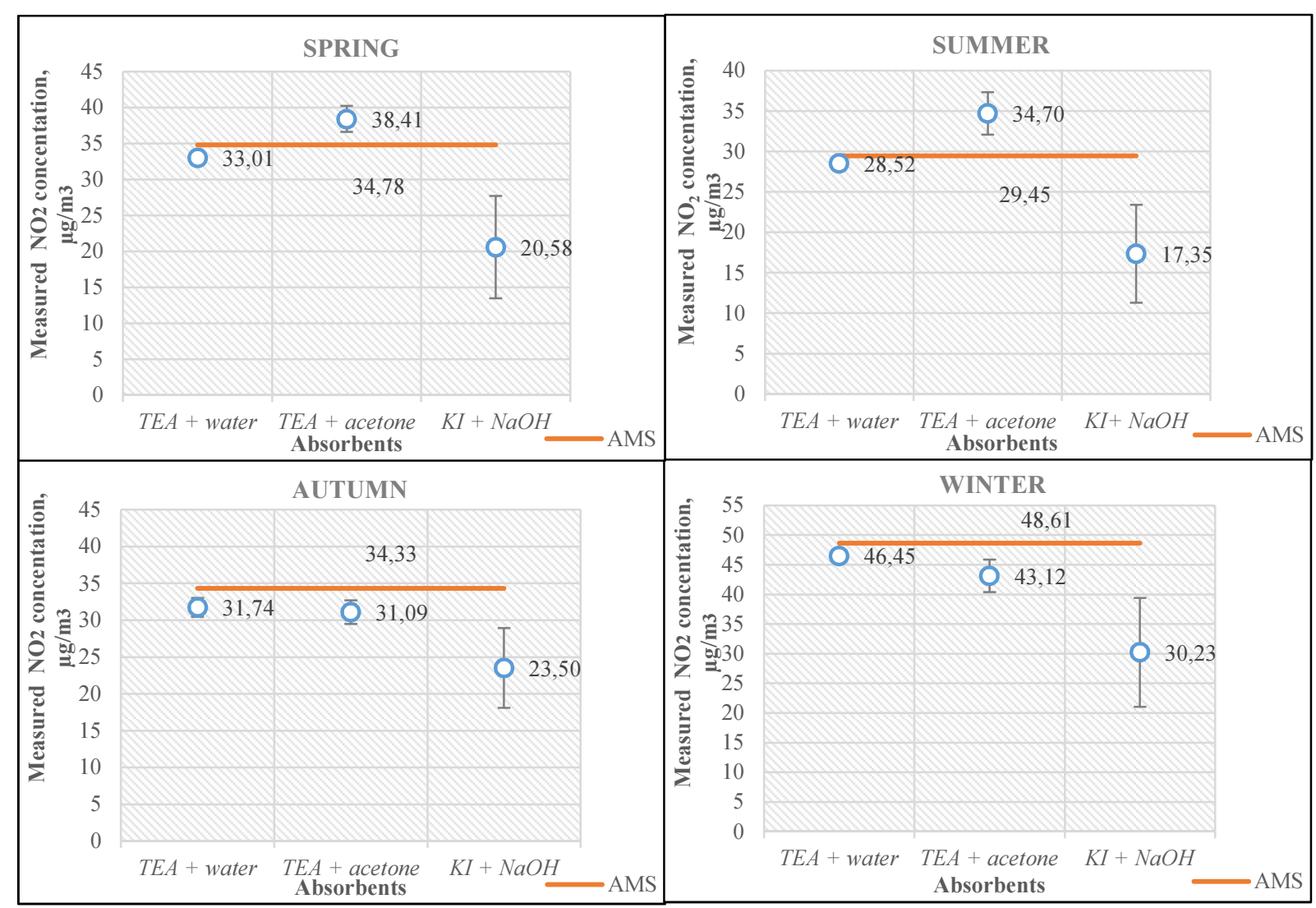

Fig. 4. Comparison of measured concentrations with data provided by AMS (autumn and winter)

To sum up the studies, the highest concentrations derived from passive samplers impregnated with TEA + acetone. Though, these results did not differed significantly to compare to the concentrations measured with TEA + water as the samplers impregnated by $\mathrm{KI}$ and $\mathrm{NaOH}$. Estimated relative errors while considering AMS data during all the perdiod of investigations starting from spring were $\pm 5.09 \%, \pm 3.16 \%, \pm 7.53 \%, \pm 4.45 \%$, respectively (for passive samplers with $10 \%$ of TEA diluted in water). Lower accuracy derived from passive samplers impregnated with $10 \%$ of TEA diluted in acetone $( \pm 10.44 \%, \pm 17.83 \%, \pm 9.42 \%, \pm 11.30 \%$, respectively), while samplers impregnated with potassium iodide plus sodium hydroxide were completely inaccurate: $\pm 40.82 \%, \pm 41.09 \%, \pm 31.53 \%, \pm 37.82 \%$ (under the Directive 2008/50/EC the data quality objective for diffusive monitoring of $\mathrm{NO}_{2}$ is determined to be $\pm 25 \%$ ). 


\section{Conclusions}

1. The correlation between nitrogen dioxide and meteorological factors (wind speed, temperature, relative humidity) in all cases appeared insignificant (significance level $p$ was higher than 0.05). The highest concentration, measured near the district road as well as air monitoring station was in winter time, the lowest - in summer. During all investigation period concentration was higher in the leeward side from the road.

2. There was determined a strong negative correlation between the concentration of nitrogen dioxide and distance from the road. By considering different seasons and absorbents, Pearson coefficient varied from -0.859 to -0.967 with 0.000 significance level $(p)$. The highest correlation was determined in winter season when $10 \%$ of TEA diluted in water was used as an absorbent.

3. The relative errors, to compare to the AMS data, derived from passive samplers impregnated with $10 \%$ of TEA diluted in water during all the period of investigations starting from spring were $\pm 5.09 \%, \pm 3.16 \%, \pm 7.53 \%, \pm 4.45 \%$, respectively. Passive samplers impregnated with $10 \%$ of TEA diluted in acetone have shown lower accuracy: $\pm 10.44 \%, \pm 17.83 \%$, $\pm 9.42 \%, \pm 11.30 \%$, respectively, while samplers impregnated with potassium iodide plus sodium hydroxide were completely inaccurate: $\pm 40.82 \%, \pm 41.09 \%, \pm 31.53 \%, \pm 37.82 \%$. Both aqueous and acetone solutions complies with the Directive 2008/50/EC requirement for uncertainty $(<25 \%)$, while the solution of potassium iodide plus sodium hydroxide exceeds the standard about 1.5 times.

\section{References}

[1] AEA Energy \& Environment [online] 2008. Diffusion Tubes for Ambient NO2 Monitoring: Practical Guidance for Laboratories and Users [cited 6 January 2013]. Available from internet: http://laqm.defra.gov.uk/documents/0802141004_NO2_WG_PracticalGuidance_Issuela.pdf

[2] Aplinkos apsaugos agentūra [online] 2012. Oro kokybè aglomeracijoje ir zonoje, [cited 10 January 2013]. Available from internet: http://oras.gamta.lt/files/Apzvalga_2011_final.pdf

[3] Baltrènas, P.; Kazlauskienè, A.; Mikalajūnè, A. 2012. Roads Environment Protection. Monograph. VGTU Press Technika. 384 p.

[4] Beckerman B.; Jerrett, M.; Brook, J. R.; Verma, D. K.; Arain, M. A.; Finkelstein, M. M. 2008. Correlation of nitrogen dioxide with other traffic pollutants near a major expressway, Atmospheric Environment 42: 275-290. http://dx.doi.org/10.1016/j.atmosenv.2007.09.042

[5] Berglund, M.; Bostrom C.E.; Bylin, G.; Ewertz, L.; Gustafsson, L.; Modeus, P.; Norberg, S.; Pershagen, G.; Victorin, K. 1993. Health Risk Evaluation of Nitrogen Oxides, Scandinavian Journal of Work, Environment and Health 19(9): 1-72.

[6] Cape, J. N. 2009. The Use of Passive Diffusion Tubes for Measuring Concentrations of Nitrogen Dioxide in Air, Critical Reviews in Analytical Chemistry 39(4): 289-310. http://dx.doi.org/10.1080/10408340903001375

[7] Costabile, F.; Allegrini, I. 2007. Measurements and analysis of nitrogen oxides and ozone in the yard and on the roof of a street-canyon in Suzhou, Atmospheric Environment 41: 6637-6647http://dx.doi.org/10.1016/j.atmosenv.2007.04.018.

[8] Cox, R. M. 2003. The use of passive sampling to monitor forest exposure to O3, NO2 and SO2: a review and some case studies, Environmental Pollution 126: 301-311. http://dx.doi.org/10.1016/S0269-7491(03)00243-4

[9] De Santis, F.; Dogeroglu, T.; Fino, A.; Menichelli, S.; Vazzana, C.; Allegrini, I. 2002. Laboratory development and field evaluation of a new diffusive sampler to collect nitrogen oxides in the ambient air, Analytical and Bioanalytical Chemistry 373: 901-907. http://dx.doi.org/10.1007/s00216-002-1368-x

[10] Delgado-Saborit, J. M.; Esteve-Cano, V. 2006. Field study of diffusion collection rate coefficients of a $\mathrm{NO}_{2}$ passive sampler in a Mediterranean coastal area, Environmental Monitoring and Assessment 120: 327-345. http://dx.doi.org/10.1007/s10661-005-9065-9

[11] Ferm, M.; Rodhe, H. 1997. Measurements of air concentrations of $\mathrm{SO}_{2}, \mathrm{NO}_{2}$ and $\mathrm{NH}_{3}$ at rural and remote sites in Asia, Journal of Atmospheric Chemistry 27: 17-29. http://dx.doi.org/10.1023/A:1005816621522

[12] Gilbert, N. L.; Woodhouse, S.; Stieb, D. M.; Brook, J. R. 2003. Ambient nitrogen dioxide and distance from a major highway, The Science of the Total Environment 312: 43-46. http://dx.doi.org/10.1016/S0048-9697(03)00228-6

[13] Gorecki, T.; Namiesnik, J. 2002. Passive sampling, Trends in analytical chemistry 21(4): 276-291. http://dx.doi.org/10.1016/S0165-9936(02)00407-7

[14] Gražulevičienè, R.; Laurinavičienè, D. 2001. Oro taršos azoto dioksidu sklaida Kaune ir jos ryšys su miokardo infarkto sergamumu. Aplinkos tyrimai, inžinerija ir vadyba 1(15): 23-29.

[15] Gurevičienè, A.; Kazlauskienè, A. 2009. Investigation into dustiness on Veisiejai-Viktarinas-Paliepiai gravelled road treated with calcium chloride, Science - Future of Lithuania 1(4): 101-104.

[16] Kazlauskienè, A.; Pottala, J.; Petronis, V. 2008. Research of dustiness on gravelled roads in Lithuania, in The $7^{\text {th }}$ International Conference "Environmental Engineering": selected papers, May 22-23, 2008. Vilnius, Lithuania. Vol. 1. Vilnius: Technika, $169-174$.

[17] Kean, A.; Harley, R.; Kendall, G. 2003. Effects of Vehicle Speed and Engine Load on Motor Vehicle Emission. Environmental Science \& Technology 37(17): 3739-3746. http://dx.doi.org/10.1021/es0263588

[18] Kirby, C.; Fox, M. Waterhouse, J. 2000. Reliability of nitrogen dioxide passive diffusion tubes for ambient measurement: in situ properties of the triethanolamine absorbent, Journal of Environmental Monitoring 2: 307-312. http://dx.doi.org/10.1039/b003124k

[19] Laurinavičienè, D. 2010. Distribution of Nitrogen Dioxide Concentration in Kaunas 2003-2007, Aplinkos tyrimai, inžinerija ir vadyba 4(54): 5-12.

[20] Laxen, D.; Wilson, P. [online] 2002. Compilation of Diffusion Tube Collocation Studies Carried out by Local Authorities [cited 18 January 2013]. Available from internet: http://uk-air.defra.gov.uk/reports/cat06/NO2DiffusionTubePerformance(Final).pdf

[21] Mikelsonaite, N.; Kazlauskienè, A. 2011. Raseinių rajono oro užterštumo $\mathrm{NO}_{2}$ ir $\mathrm{SO}_{2}$ tyrimai, taikant pasyviujų sorbentų bei bioindikacinius metodus. Mokslas - Lietuvos ateitis 3(5): 43-49. http://dx.doi.org/10.3846/mla.2011.085

[22] Seinfeld, J. H.; Pandis, S. N. 2006. Atmospheric chemistry and physics: From air pollution to climate change, $2^{\text {nd }}$ edition. John Willey n Sons, Inc., New Jersey, 2006. p. 1232. ISBN: 978-0-471-72018-8.

[23] Šerevičienè, V. 2012. Research and Development of Nitrogen Dioxide Diffusive Samplers. Doctoral Dissertation. Vilnius: Technika, 2012, p. 148

[24] Šerevičienè, V.; Paliulis, D. Assessment of air quality using diffusive samplers and ADMS-Urban, Ekologija 57(3): 129-136.

[25] Šerevičienè, V.; Valuntaitė, V.; Paliulis, D. 2010. Impregnuojančio tirpalo įtakos difuzinių kaupiklių efektyvumui eksperimentiniai tyrimai. Mokslas Lietuvos ateitis 2(5):103-108. http://dx.doi.org/10.3846/mla.2010.100

[26] Silva, A. S.; Cardoso; M. R.;Meliefste, K.; Brunekreef, B. 2006. Use of passive diffusion sampling method for defining NO2 concentrations gradient in São Paulo, Brazil, Environmental Health: A Global Access Science Source 5:19. 
[27] Stranger, M.; Krata, A.; Kontozova-Deutsch, V.; Bencs, L.; Deutsch, F.; Worobiec, A.; Naveau, I.; Roekens, E.; Van Grieken, R. 2008. Monitoring of $\mathrm{NO}_{2}$ in the ambient air with passive samplers before and after a road reconstruction event, Microchemical Journal 90: 93-98. http://dx.doi.org/10.1016/j.microc.2008.04.001

[28] Tang, Y. S.; Cape, J. N.; Sutton, M. A. 2001. Development and types of passive samplers for monitoring atmospheric $\mathrm{NO}_{2}$ and $\mathrm{NH}_{3}$ concentrations, in Proceedings of the international symposium on passive sampling of gaseous air pollutants in ecological effects research, Scientific World 1: 513-529. http://dx.doi.org/10.1100/tsw.2001.82

[29] Toxico-Logic Consulting Inc. [online] 2007. Assessment Report on Nitrogen Dioxide for Developing Ambient Air Quality Objectives [cited 20 May 2013]. Available from internet: http://environment.gov.ab.ca/info/library/8302.pdf

[30] Tsai, W.Y.; Chan, L. Y.; Blake, D. R.; Chu, K. W. 2006. Vehicular fuel composition and atmospheric emissions in South China: Hong Kong, Macau, Guangzhou, and Zuhai, Atmospheric Chemistry and Physics 6: 3281-3288. http://dx.doi.org/10.5194/acp-6-3281-2006

[31] Vainalavičiūtè, R.; Kazlauskienè, A.; Baltrènas, P.; Jankaitè, A. 2009. Investigation of particulate matter and chloride concentrations in the environment of gravelled roads, Geologija 51(1): 1-11.

[32] Valuntaitè, V.; Šerevičienė, V.; Girgždienè, R.; Paliulis, D. 2012. Relative humidity and temperature impact to ozone and nitrogen oxides removal rate in the experiment chamber, Journal of Environmental Engineering and Landscape Management 20(1): 35-41. http://dx.doi.org/10.3846/16486897.2011.633335

[33] Villena, G.; Bejan, I.; Kurtenbach, R.; Wiesen,P.; Kleffmann, J. 2012. Interferences of commercial NO2 instruments in the urban atmosphere and in a smog chamber, Atmospheric Measurements Techniques 5: 149-159. http://dx.doi.org/10.5194/amt-5-149-2012 